\title{
The Ideology of Resistance in Tempurung Novel by Oka Rusmini: Critical Discourse Analysis Study
}

\author{
Eko Hardinanto \\ Doctoral Program of Language and Literature Education, Universitas Negeri Surabaya \\ Lidah Wetan, Surabaya - Indonesia \\ Setya Yuwana Sudikan \\ Language and Literature Education Study Program, Postgraduate School, Universitas Negeri Surabaya \\ Lidah Wetan, Surabaya - Indonesia \\ Tengsoe Tjahjono \\ Language and Literature Education Study Program, Postgraduate School, Universitas Negeri Surabaya \\ Lidah Wetan, Surabaya - Indonesia
}

\begin{abstract}
This research aims to find, describe, interpret, and explain the ideology of women against the domination of patriarchy, myths and customs in Oka Rusmini's Tempurung novel. The approach used in this research is descriptive qualitative. This study uses critical discourse analysis as a blade of analysis. The data source in this study is the Tempurung novel by Oka Rusmini, published by PT. Gramedia Widiasarana Indonesia in 2017. The steps taken in data collection are as follows: read over and over the whole novel to understand its contents completely, record important words, sentences, or data related to the problem under study, record and collect relevant theories related to research, conduct research based on existing theories, and draw conclusions. The steps in data processing are as follows: data description, data classification, data analysis, data interpretation, and evaluation. The data analysis techniques used were: processing and presenting data, reading the entire data, coding the data and descriptions, interpreting and explaining the data. The findings in this study are that the Tempurung novel is a reflection of the ideology of women's resistance to the patriarchal system, the ideology of fighting against myths created by patriarchy, and the ideology of resistance to tradition. The resistence is done to obtain equality in their rights and obligations, so that women can get freedom like men. The female characters in the Tempurung novel fight against the domination of patriarchy, myths, and their own cultural customs in order to realize equal rights between men and women.
\end{abstract}

Keywords: resistance, patriarchy, myth, custom, Critical Discourse Analysis

DOI: $10.7176 / J L L L / 73-04$

Publication date: November $30^{\text {th }} 2020$

\section{Introduction}

Tempurung novel is one of the novels by Oka Rusmini. In the novel, Oka Rusmini explores Bali which is famous for its culture and customs which are very firmly held by its people. In Balinese customary law there is a caste system, which is a system that is closely related to Hinduism and all of its instruments and is considered something related to God's gift. The caste system is seen as something that is inherited and is rigid, binding and difficult to change (Eriksen, in Anwar, 2016).

In the view of critical discourse analysis, discourse is seen as an ideological practice or a reflection of a particular ideology (Fairclough, 1995: 14). The ideology behind the production of the text will always color a certain form of discourse. According to Santoso (2012: 126) there are two important notes relating to ideology in discourse. First, ideology is inherently social, not personal or individual. Ideology always requires members of a group, community, or society who adhere to and fight for that ideology. Second, ideology is used internally among members of a group or community. Ideology always provides answers about group identity. In discourse analysis (critical) will always take sides with the oppressed, subordinated, hegemonic, and determined. Discourse analysts must depart from the awareness that there is a lot of powerlessness in the marginalized community towards the domination of public discourse and the task of analysis is to empower that community (Santoso, 2012: 23). Therefore, many formulations have emerged that in order to analyze discourse on social issues, a paradigm labeled as critical is needed, not a descriptive paradigm that only tries to provide a mere phenomenon.

Critical discourse analysis that refers to Fairclough's thoughts from the book Critical Discourse Analysis combines the tradition of textual analysis with the wider context of society. Language as a manifestation of text is seen as a dialectical process with social structures so that the analysis will be centered on how language is formed and formed from social relations and certain social contexts. Critical discourse analysis is basically based on the idea of Marx who views society as a class system. Society is seen as domination and the media is part of 
the domination system. Thus, the media is believed (or rather suspected) as a means of domination by the dominant group over other groups.

Language in critical discourse analysis, apart from the text in a comprehensive, holistic and more complex context, is also a tool used for specific purposes and practices. There are several characteristics of critical discourse analysis, namely (1) discourse is understood as an action so that it will bring up the consequences of discourse which are seen to affect, debate, persuade, support and show how expression is conscious and expression is controlled, (2) the context of critical discourse analysis considers the context of discourse from the background., social situations and conditions, (3) history which is an important aspect in understanding discourse by placing the discourse in a certain historical context, (4) critical discourse analysis also considers the element of power in its analysis. Therefore, critical discourse analysis does not only focus on the structure of discourse in linguistic terms, but also connects with the context, and looks historically by adding aspects of social cognition and ideology, so that the analysis is not limited to closed language placement but looks at the context of how the ideology is. play a role in shaping a discourse.

Fairclough builds a discourse analysis model that has a contribution that includes a combination of textuality and seeing closed spaces with the wider context of society. Then this model is intended to integrate discourse analysis based on linguistics, regarding social change. Using discourse that refers to the use of language as a social practice which has implications that will be more meaningful than individual activities or to reflect something, because discourse is a form of someone's action to use language as an action to the world, especially as a form of representation when seeing the world of reality. Then this model implies a reciprocal relationship between discourse and social structure. Norman Fairclough (Badara, 2012: 26) argues that discourse is a social practice and divides discourse analysis into three dimensions, namely: text, discourse practice, and social practice. Text is related to linguistics, for example by looking at vocabulary, semantics, and sentence structure, as well as coherence and cohesion, as well as how these units form a sense. Discourse practice is a dimension related to the process of producing and consuming text. Social practice, a dimension related to contexts outside the text; for example the context of the situation or the context of the media in relation to a particular society or political culture.

Based on this explanation, a critical discourse analysis is formulated, namely an in-depth study that seeks to reveal activities, views and identities based on the language used in the discourse. Discourse analysis using the Fairclough critical approach shows the integration of: (a) text analysis; (b) analysis of the process of production, consumption and distribution of text; and (c) the sociocultural analysis that develops around the discourse. The three forms of analysis constitute one unified whole. This gives the understanding that in order to analyze a text / discourse in depth one must carry out the analysis of the text / discourse as a whole. In the sociocultural dimension, it can be seen that texts are influenced and shaped by socio-culture, including the context of situations, institutions, and social change.

Fairclough describes the three-dimensional model of Critical Discourse Analysis as follows

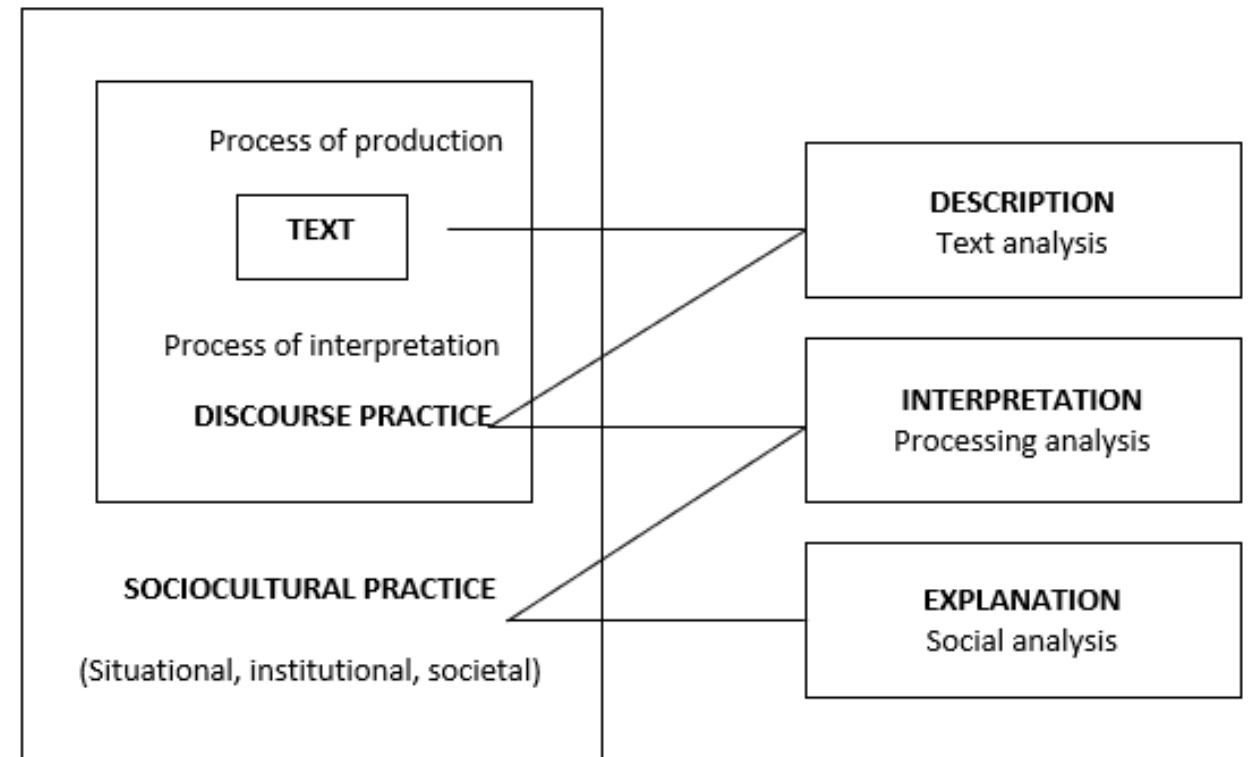

Dimensions of discourse

\section{Dimensions of discourse analysis}

Chart 1

Fairclough's Three-Dimensional Model of Critical Discourse Analysis Source: Fairclough (1995: 98) 
Chart 1 consists of two charts, namely the discourse dimension and the discourse analysis dimension. The dimension of discourse is the dimension of the author, while the dimension of discourse analysis is the dimension of the readers / interpreters. Text (media, novel) always goes through a process of production and a process of interpretation. Both production and interpretation processes are strongly influenced by sociocultural practice.

With the existence of many types of critical discourse analysis, it makes critical discourse analysis very diverse theoretically and analytically. Conversational analysis / critical conversation is very different from news analysis or learning. But in fact there is the same perspective and objective of Critical Discourse Analysis, namely regarding the structure of discourse related to the reproduction of social domination, whether it is in the form of conversations or news or other genres and contexts. The scope of study that is often discussed in critical discourse analysis is power, domination, hegemony, ideology, class, gender, race, discrimination, interests, reproduction, institutions, social structures or social order. Critical discourse analysis research often refers to well-known critical social scientists and philosophers such as the Frankfurt School, Habermas, Foucault and so on or the neo-Marxist school when they want to theorize and understand them. Furthermore, to find a theoretical framework it is best to focus on basic concepts related to discourse, cognition, and society.

\subsection{Characteristics of Critical Discourse Analysis}

Critical discourse analysis sees language as an important factor, namely how language is used to see power imbalances in society. Quoting Fairclough and Wodak (Badara, 2012: 29), critical discourse analysis investigates how the use of the language of existing social groups battles each other and proposes their respective versions. Eriyanto (2005: 8-13) states that there are several characteristics of critical discourse analysis based on the opinions of Van Dijk, Fairclough and Wodak, namely action, context, history, power and ideology.

\subsubsection{Action}

The first principle, discourse is understood as an action. With such understanding, discourse is associated as a form of interaction. Discourse is not placed as in a closed and internal space. Discourse is seen as something that aims, whether to influence, argue, persuade, argue, react, and so on. A person speaking or writing has a specific purpose, both big and small. In addition, discourse is also understood as something that is expressed consciously, controlled, not something that is out of control or expressed outside of consciousness.

In critical discourse analysis, discourse is not only understood as a study of language. According to Darma (2009: 135) language is analyzed not only by describing the aspect of language but expressing it with action. Discourse analysis investigates social groups that struggle through language. Critical discourse is also a discourse that is not neutral. Various approaches are used to debate opinions between one group and another. There are those who act on behalf of gender so that they are considered siding with oppressed social groups.

Based on the above description, it can be concluded that critical discourse is not only a writing but is an act of the author, this discourse contains objectives for example to debate, persuade, react and so on. This discourse is also something that is expressed consciously and in control. Some critical discourses in Indonesia, for example in novels, contain certain objectives to influence or debate a group or group. To understand this discourse requires adequate knowledge because many languages are implied, therefore many studies on critical discourse analysis have emerged.

\subsubsection{Context}

Critical discourse analysis considers the context of discourse, such as settings, situations, events, and conditions. Discourse in this case is produced, understood, and analyzed in a particular context. Referring to Cook's view (Badara, 2012: 30), discourse analysis also examines the context of communication: who communicates with whom and why; in what types of audiences and situations; through what medium; how different types of communication develop; and relationships for each of them. The study of language here includes context, because language is always in context and there is no act of communication without participants, intertext, situations, and so on. However, not all contexts are included in the analysis, only those that are relevant and have an effect on the production and interpretation of texts that are included in the analysis.

\subsubsection{Historical}

Discourse positioned in a particular social context means that discourse is produced in a certain context and cannot be understood without including the accompanying context. One important aspect of being able to understand a text is placing the discourse in a certain historical context.

\subsubsection{Power}

In critical discourse analysis, elements of power are also considered in the analysis. Every discourse that appears, in the form of text, conversation or whatever, is not seen as something natural, natural, and neutral but is a form of power struggle. The concept of power is one of the key relationships between discourse and society. For example, men's power over women in the discourse of sexism or corporate power in the form of domination by upper-class entrepreneurs to their subordinates.

This power is needed to see what is called control. One person or group controls another group, and a 
dominant group has more access than a non-dominant group. Power or social power is the central study of critical discourse. Power is used to control the actions and thoughts of a group in the form of money, status, popularity, knowledge, information, culture and communication. Power is differentiated based on the resources that use it. For example, a rich person has the power of money and a lot of wealth, a scientist has power because of his knowledge. The power of a group is integrated in the form of laws, regulations, norms, habits or consensus which is usually called hegemony. The sources of power can be politics, media, or science. Then the process affects a person's mind and indirectly controls his actions. When one's mind has been influenced by texts and speech, this proves that discourse can control people's actions through persuasion and manipulation.

\subsubsection{Ideology}

Ideology has two contradictory meanings. Positively, ideology is perceived as a world view which states the value of certain social groups to defend and advance their interests. As for negatively, ideology is seen as a false consciousness, namely a need to commit deception by distorting people's understanding of social reality. A text can never be separated from ideology and has the ability to manipulate the reader towards an ideology.

\section{Transitivity}

\subsection{Transitivity Theory}

The choice of transitivity system is very prominent among the choices for grammatical forms in discourse (Santoso, 2012: 193). Basically, this transitivity theory originates from the function of language representation, namely the function of language which has the duty to (1) encode our experience of the world, and (2) bring a picture of reality. According to Halliday (1984: 101), the fundamental possession of language allows humans to construct mental images of reality, making meaning from experiences of what is happening around them and in them. These mental images can be in the form of sentence structures, phrases, clauses, and even words. Halliday emphasizes the role of clauses / sentences because it is the clause / sentence that plays a very important role in the embodiment of various processes. The clause is a very significant grammatical unit because the clause performs the function of representing these processes. This can make it easier to analyze the contents of the text in the form of ideology, power and certain interests.

\subsection{The Transitivity Perspective}

Transitivity system is related to Halliday's thinking. According to Halliday (in Santoso, 2012: 193) our understanding of the reality of "what is going on" (goings-on) can be: doing, happening, feeling, and being. What is happening is sorted out in the semantic system of a language and then manifested through clauses. This is what is called a "transtivity system". Transitivity systems will describe the various processes involved and the structures that make them happen.

A process semantically contains three components, namely (1) the process itself, (2) the participants involved in the process, and (3) the related information or circumstances in the process. There are three main types of processes, namely (1) material processes, (2) relational processes, and (3) projection processes (Butt et al., 1995: 46-51). In the previous classification, Halliday (1984) divides the main processes into: material processes, mental processes, and relational processes.

According to Santoso (2012: 195), there are three important things that are of concern in the transitivity system, namely (1) what types of processes and participants are dominant or prominent, (2) how the agent is shown, and (3) the processes whatever is shown. In Fairclough's (1989: 120) view, when a person provides a textual representation of real or imaginary actions, events, circumstances, and relationships, there is often a choice between different types of processes and participants and the selection made is ideologically significant.

\section{Method}

This study uses a qualitative descriptive approach, with a critical discourse analysis knife by Norman Fairclough's model. Critical discourse analysis is multidisciplinary, because it includes several disciplines; linguistics, sociology, anthropology, communication, and literature. To analyze the field of literature (novel), a qualitative descriptive approach with critical discourse analysis analysis knife is very suitable because novel can not only be interpreted as a mirror of people's life where some of the events that occur in people's lives cannot be explained by statistical data that is usually used in quantitative research. novels also contain hidden ideologies. To uncover this hidden ideology, a suitable analysis is needed, namely critical discourse analysis.

The source of data in this study is Oka Rusmini's Novel Tempurung published by PT. Gramedia Widiasarana Indonesia, Jakarta, member of Ikapi, Jakarta 2017. The data used in this research is written data. Data according to the research focus is presented in the form of words, phrases, sentences and paragraphs. The data is a source of information that will be described and contain an explanation of the ideology of women in Oka Rusmini's novel Tempurung. These data are data which in essence contain lingual features that carry ideology (transitivity system). This study uses documentation data collection techniques. The data analysis technique in this study used Norman Fairclough's critical discourse analysis method. To test the validity of this 
research data, the authors conducted triangulation techniques, discussions with experts, discussions with authors, and discussions with peers.

\section{Data analysis}

In this data analysis, several things are analyzed and discussed, namely; (1) the ideology of resistance to patriarchal domination, (2) the ideology of resistance to myths created by patriarchy, and (3) the ideology of resistance to adat.

\subsection{The ideology of resistance to patriarchal domination}

The interactions that Oka Rusmini made with her family and the surrounding community gave her views, which gave rise to ideas in the form of certain ideologies. One of these ideologies is the ideology of resistance to patriarchal domination. This can be seen in the novels it produces. Oka Rusmini makes use of lingual tools to convey meaning as an expression of his heart.

In conveying the ideology that is placed in his novels, Oka Rusmini makes use of lingual features which are aimed at strengthening the planting of the ideology he carries. One of the utilization of these lingual features is the transitivity system. According to Halliday (1994), transitivity includes three types, namely: material processes (actions), mental processes (projections), and relational processes (becoming). The material process includes; process of deeds, events, and behavior. Mental processes include the processes of perception, affection, and cognition. The relation process includes: attribute, identification, and existential.

In the novel Tempurung, the character Sipleg shows his view on the marriage bond. The attitude of the Sipleg character is shown through an assessment of the man whom he calls father. Sipleg sees that men just keep sowing seeds in their mother's stomach. For the character of Sipleg, his mother is like a factory whose job is only to procreate and give birth to the point of not taking care of herself. Sipleg sees her mother as a woman who doesn't respect her own body. Sipleg considers her mother like an idiot who only believes in what men say. This can be found in the following data:

(1) “....Lelaki satu-satunya di rumah hanya bapak, yang hanya bisa menaburkan benih di perut ibunya...Ibunya mirip pabrik bayi dibanding manusia. Kerjanya hanya mengandung, sampai tidak sempat merawat diri. Tubuhnya kurus.Bayi yang dilahirkan selalu prematur. Semua itu karena perempuan tolol itu sangat percaya pada lelaki yang mengawininya" (Rusmini, 2017: 79).

(".... The only man in the house is only the father, who can only sow the seeds on his mother's stomach... His mother is like a baby factory compared to humans. The job is only pregnant, until she doesn't have time to take care of herself His body is thin. Babies who are born are always premature. All because the stupid woman really believes in the man who married her")

The use of grammatical elements in the form of a transitivity system through mental processes with a choice of affection processes can be found in data (1) in bold clauses. Analysis of the data transitivity is as follows:

\begin{tabular}{|l|l|l|l|}
\hline The stupid woman & Really believes in & The man & Who married her \\
\hline Actor & Mental process & Goal & Information \\
\hline
\end{tabular}

Data (1) shows that Sipleg dislikes maltreatment by men to women. According to Sipleg, his mother should refuse not to always carry a baby. Women should be able to take good care of their bodies. Because the body belongs to the woman herself and must be able to protect it.

Within the radical feminist concept, there is an attitude like that of Sipleg that women should not constantly torture their bodies, by continuing to allow flesh to grow in their bodies. What Sipleg wants for women is an awareness of her that her body is her precious possession.

\subsection{The ideology of fighting against myths created by patriarchy}

Girls who can't have sons are unlucky girls. Without male descendants to live to the end of the world, this is the concept of men against women who cannot give birth to sons. The stupidity of women is to believe these words. Sipleg can't stop thinking that the woman she calls the mother keeps letting her body be fed with meat just to be able to give birth to a baby boy. For Sipleg it is only a foolish woman who allows her body to be covered with flesh. The woman who made him appear more inanimate than inanimate. This can be seen in the following data:

(2) "Kata bapak, perempuan yang tidak bisa melahirkan bayi lelaki adalah perempuan sial! Hidup tanpa keturunan lelaki kiamat! Hidup itu sudah mati tanpa lelaki! Dan, si tolol itu percaya. Sipleg tidak bisa menghitung berapan puluh bayi yang dilahirkan mati! Hanya untuk mendapatkan bayi lelaki, perempuan itu membiarkan tubuhnya dititipi daging terus-menerus. Daging yang memakan isi tubuhnya. Perempuan tolol itu lebih mirip benda mati dibandingkan benda hidup" (Rusmini, 2017: 79).

("Father said, a woman who can't give birth to a boy is an unlucky woman! Life without male descendants doomsday! Life is dead without a man! And, the idiot believed. Sipleg can't count 
the dozens of stillborn babies! Just to have a baby boy, the woman allowed her body to be fed with meat constantly. Meat that eats the contents of his body. This stupid woman looks more like an inanimate object than a living thing ")

In data (2), the author utilizes grammatical elements in the form of a transitivity system through the identification process. This data can be analyzed with a transitivity system as follows:

\begin{tabular}{|l|l|l|}
\hline A woman who can't give birth to boy & Is & An unlucky woman \\
\hline Identifier & Identification process & Identified \\
\hline
\end{tabular}

Data (2) explains that for men, women who cannot give birth to sons are unlucky women. Giving birth to a boy is a must for girls. This means that women think that they will be perfect when they can give birth to a boy. Life without a son is death and doomsday for a man. The attitude shown by my character illustrates the radical feminist point of view that women do not have to allow their bodies to be hurt. What Sipleg wants as a woman is the courage of a woman to reject the treatment she doesn't deserve.

\subsection{The ideology of resistance to tradition}

The female characters in the novel Tempurung also fight against adat. One of the characters in the novel who is against adat is Dayu. This can be found in the following data:

(3) "Ketika kau datang, kau terlihat seperti makhluk aneh. Kau baik pada wong jero, abdi perempuan. Kau baik pada parekan, abdi lelaki. Kau menganggap mereka teman, sederajat. Cinta mereka padamu terlihat tulus. Tidak seperti kepadaku yang sering berkata kasar pada mereka. Tetapi kau juga aneh. Kau menentang banyak hal. Kau ingat, sampai keluarga besarmu mengadakan upacara untukmu!" (Rusmini, 2017: 155)

("When you came, you looked like a strange creature. You are kind to Wong Jero, servant girl. You're good at parekan, man. You consider them friends, equals. Their love for you seems sincere. Unlike me who often said harshly to them. But you're weird too. You against a lot of things. You remember, until your extended family held a ceremony for you!")

In this data, the author utilizes grammatical elements through a transitivity system with a material process in the form of an action process. Transitivity analysis is as follows:

\begin{tabular}{|l|l|l|l|}
\hline You & Against & A lot of things & 0 \\
\hline Actor & Action process & Goal & Information \\
\hline
\end{tabular}

The data shows Dayu's response against existing customary rules. Dayu was always kind to male servants and female servants. Whereas according to Jelangga as an Ida Ayu, Dayu should keep a distance from the servants. Dayu is considered higher in rank than the Servants. However, Dayu always defied the rules and tried to act casual, as if she and the servants had the same rank.

\section{Discussion}

The results of this research analysis are in the form of describing the problem under study in the form of a narrative description, and generally answering the questions according to the focus of the research. In this discussion, issues related to the ideology of resistance related to the relationship between women and men were also explained in Oka Rusmini's novel Tempurung through a process of critical discourse analysis using the Fairclough model. Descriptions, interpretations and explanations of the data are compiled thoroughly and systematically in their pouring. The results of the analysis and discussion are presented as follows.

Based on the results of the study of the novel Tempurung by Oka Rusmini, several discussions can be stated according to the results of the analysis, that through critical discourse analysis, namely an analysis of the ideology of resistance related to the relationship between women and men in the process of social relations and institutions, it is found that the position of women and men reflects their existence. feminist expression that tends to fight against social differentiation between women and men. This gives the researchers the view that as the author Oka Rusmini has included the ideology of resistance in the novel he produces. This ideology is the ideology of resistance to patriarchal domination. Some of the female characters in the novel enter into the tradition of male professions, even with their activities which have very important social implications in the process of institutional relations, which can potentially undermine the patriarchal culture and stratification patterns that develop regarding the status and role of women in public area. Female characters in Oka Rusmini's novel Tempurung have a typical relationship with their cultural background, and the ideological representation of resistance is found through their attitudes and actions that have fought and liberated themselves from the rules, culture, traditions, values and norms of society, both in the process of social and institutional relations. These figures carry out a movement of self-liberation from the power structure, giving rise to a spirit of resistance to the authority of power, be it power, patriarchy, traditions, and moral values.

\section{Conclusion}

Tempurung novel is a reflection of the ideology of women's resistance to the patriarchal system, the ideology of 
fighting against myths created by patriarchy, and the ideology of resistance to tradition. The women's ideology in Tempurung novel is depicted through female characters. Through her novel, Oka Rusmini describes the figure of women's struggle by looking at the other side of women, namely from the side of women's freedom. One of them is freedom in choosing a life partner. Oka Rusmini also described female figures as a woman who opposed the prevailing customs in Bali. The story of the struggles of female characters in achieving happiness and facing the socio-cultural reality around them is what Oka Rusmini raises in her novels. Balinese society is known for its caste system, which is the grouping of social classes based on birth / descent. This has an impact on the marriage system and various Balinese cultural customs regulations that actually shackle Balinese women themselves. Basically all humans are born the same, they are born with the same rights. This results in injustice if there are groupings of social classes in society such as those in Bali. People who are brahmin caste, the highest caste in Bali, are always considered respectable, while people who are born as the Shudra caste, the lowest caste in Bali, must always respect and devote themselves to those who are born as nobles.

The female characters in the novel Tempurung also reject the myths created by patriarchy. One of these myths is the belief that women who cannot give birth to sons are unlucky women. Giving birth to a boy is a must for girls. Oka Rusmini broke the myth through the characters in the novel Tempurung.

The female characters in Oka Rusmini's novel Tempurung oppose adat, especially in the marriage system, with the hope that they will get happiness for their life choices, even though they have to bear heavy risks. From this description, it is clear that the struggles and efforts of women figures in opposing the domination of patriarchy, myths and customs that oppress women and create an ideology of resistance.

\section{References}

Anwar. (2016). "Ini Kan Bukan Bali: Interaksi Antar-Kasta Masyarakat Transmigran di Desa Kertoraharjo Kabupaten Luwu Timur Sulawesi Selatan”, Jurnal Etnosia (Vol 01 No 02).

Badara, Aris. (2012). Analisis Wacana: Teori, Metode, dan Penerapannya pada Wacana Media. Jakarta: Kencana Prenada Media Group.

Butt, David et al. (1995). Using Functional Grammar: An Explorer's Guide Sydney: National Centre for English Language Teaching and Research Maxquarie University

Darma, Yoce Aliah. (2009). Analisis Wacana Kritis. Bandung: Yrama Widya.

Eriyanto. (2005). Analisis Wacana.Yogyakarta: LkiS

Fairclough, Norman. (1998). Critical Discourse Analysis: The Critical Study of Language. London: Longman

Fairclough, Norman. (1995). Media Discourse. New York:Edward Arnold

Fairclough, Norman. (1995). Critical Discourse Analysis: The Critical Study of Language. London and New York: Longman

Halliday, M.A.K. (1994). An Introduction to Functional Grammar. London: Arnold.

Oka Rusmini. (2017). Tempurung. Jakarta: PT. Gramedia Widiasarana Indonesia

Santoso, Anang. (2012). Studi Bahasa Kritis: Menguak Bahasa Membongkar Kuasa. Bandung: Penerbit CV Mandar Maju. 